3. M.B. Klein and R.N. Schwartz, J. Opt. Soc. Am. B, 3 (2), (1986) p. 293-305.

4. B. Tuttle, J. Voigt, E. Binasiewicz, and K. Kimball, Sandia Report No. SAND87-1824 (1987).

5. A.M. Glass, Opt. Eng. 17 (6), (1978) p. $470-479$.

6. R.E. Newnham, presented at the 1987 Annual Meeting of the American Ceramic Society, Pittsburgh, PA, Orton Memorial Lecture, 1987 (unpublished).

7. H. Tscuchiya and T. Fukami, Ferroelectrics 63 (1985) p. 299-308.

8. T. Kishimoto and T. Ohsaki, IEEE Trans. Comp. Hybrids and Man. Tech., CHMT-9 (4) (1986) p. 328-335.

9. R. Holman, L. Althouse Johnson, and D. Skinner, in Proceedings of the Sixth IEEE Int. Symp. on Appl. of Ferroelectrics, (1986) p. 3241.

10. A. Yariv, Introduction to Optoelectronics (Holt, Rinehart and Winston, Inc., New York, 1971) p. 230-245.

11. E. Wu, J. Ratto, J. Oliver, and R. Neurgaonkar, in Proceedings of the Sixth IEEE Int. Symp. on Appl. of Ferroelectrics, (1986) p. $478-481$.

12. D. Rytz and H. Scheel, J. Cryst Growth 59, (1982) p. 468-484.

13. J.C. Baumert, C. Walther, P. Buchmann, H. Kaufmann, H. Melchior, and P. Gunter, Appl. Phys. Lett. 46 (11) (1985) p. 1018 .

14. O. Khachaturyan and R. Madoyan, Cryst. Res. and Tech. 19 (4) (1984) p. 461-466. 15. P. Bohac, Proc. Sixth Intl. Mtg. on Ferroelectricity, Ipn. J. of Appl. Phys. 24, Supplement 24-2 (1985) p. 613-615.

16. R.R. Neurgaonkar and W.K. Cory, I. Opt. Soc. Am. 3 (2), (1986) p. 274.

17. O. Eknoyan, C. Bulmer, H. Taylor, W. Burns, A. Greenblatt, L. Beach, and R. Neurgaonkar, Paper THBB1 (Integrated and Guide-Wave Optics Conference, 1986).

18. V.D. Antsigin, W.M. Egorov, E.G. Kotsov, V.K. Malinovsky, and L.N. Sterelyukhina, Ferroelectrics 63, (1985) p. 235242

19. H.M. Quek and M.F. Yan, Ferroelectrics 74 (1987) p. 95-108.

20. S. Hirano and K. Kato, Am. Ceram. Soc. Bull 66 (3) (1987) p. 547.

21. W. Griffel, Paper WP6 (OSA Meeting, Washington, DC, 1985).

22. S. Kondo, K. Sugii, S. Miyazawa, and S. Uehara, J. Cryst. Growth 46 (1979) p. 314322

23. G. Haertling and C. Land, J. Am. Ceram. Soc. 54 (1) (1971) p. 1.

24. M. Ishida, H. Matsunami, and T. Tanaka, Appl. Phys. Lett. 31 (7) (1977) p. 433-434.

25. M. Ishida, S. Tsuji, K. Kimura, H. Matsunami, and T. Tanaka, J. Cryst. Growth45, (1978) p. 393-398.

26. M. Ishida, H. Matsunami, and $T$. Tanaka, J. Appl. Phys. 48 (1977) p. 951.
27. T. Kawaguchi, H. Adachi, K. Setsume, O. Yamazaki, and K. Wasa, Appl. Optics 23 (13) (1984) p. 2187-2191.

28. S. Gurkovich and J. Blum, Ultrastructure Processing of Ceramics, Glasses and Composites (John Wiley and Sons, New York, 1984) p. 152.

29. K. Budd, S. Dey, and D. Payne, Br. Ceram. Proc. 36, p. 107-120.

30. S. Ducharme and J. Feinberg, J. Opt. Soc. Am. B 3 (1986) p. 283-291.

31. P. Schunemann, H. Tuller, and $H$. Jensen, Am. Ceram. Soc. Bull. 66 (3) (1987) p. 547.

32. R. Dosch, in Better Ceramics Through Chemistry, edited by C.J. Brinker, D.E. Clark, and D.R. Ulrich, (Mater. Res. Soc. Symp. Proc. 32, Elsevier, New York, 1984) p. $157-161$.

33. J. Xu, A. Shaikh, and R. Vest, Am. Ceram. Soc. Bull. 66 (3) (1987) p. 54

34. P. Chaudhari, R. Koch, R. Laibowitz,
T. McGuire, and R. Gambino, Phys. Rev Lett. 58 (25) (1987) p. 2684-2686.

35. T. Dinger, T. Worthington, W. Gallagher, and R. Sandstrom, Phys. Rev. Lett. 58 (25) (1987) p. 2687-2690.

36. K. Moriwaki, M. Suzuki, Y. Enomoto, and T. Murakami, in High Temperature Superconductors, edited by D.U. Gubser and M. Schluter (Mater. Res. Soc. EA-11, Pittsburgh, PA, 1987) p. 85-89.

37. J. Evetts, R. Somekh, M. Blamire, Z. Barber, K. Butler, J. James, G. Morris, E. Tomlinson, A. Schwarzenberger, and $W$. Stobbs, ibid, p. 227-231

38. R. Koch, R. Laibowitz, P. Chaudhari, R. Gambino, G. Clark, A. Marawich, and C. Umbach, ibid, p. 81-84.

39. R. Dosch, B. Tuttle, and R. Brooks, J Mater. Res. 1 (1), (1986) p. 90-99.

40. G. Haertling, in Ceramic Materials for Electronics, edited by R. Buchanan (Marcel Dekker, Inc., New York, 1986) p. 160.

\title{
MRS Election Results
}

The winners of the 1987 election for Officers and
Councillors are as follows:

First Vice President

(and President-Elect): ... R.P.H. Chang

Second Vice President: . Paul S. Peercy

Councillors:

B.R. Appleton

Walter L. Brown

Charles B. Duke

S. Thomas Picraux

Della M. Roy

Bob Chang and Paul Peercy will begin their one-year terms of office January 1, 1988. The Councillors will serve three-year terms, also beginning January 1, 1988. 